\title{
Evidence for limited microbial transfer of methane in a planktonic food web
}

\author{
Stuart E. Jones, Jay T. Lennon* \\ W. K. Kellogg Biological Station and Department of Microbiology and Molecular Genetics, \\ Michigan State University, 3700 East Gull Lake Drive, Hickory Corners, Michigan 49060, USA
}

\begin{abstract}
Methane-derived carbon may be an important, but overlooked source of energy fueling food webs in a variety of aquatic ecosystems. Although it is commonly assumed that the flow of methane-derived carbon is regulated by aquatic invertebrate consumption of methane-oxidizing bacteria (MOB), few studies have characterized this trophic interaction. We used stable isotope analysis, bioassay experiments, and PCR-based molecular techniques to investigate the interactions between Daphnia and MOB in the pelagic region of a humic lake located in southwestern Michigan, USA. We observed moderate depletion of ${ }^{13} \mathrm{C}$ in the plankton, but these data alone could not provide evidence for the consumption of MOB by Daphnia. Using quantitative PCR, we determined that MOB attained relatively high densities in the water column ( $3 \%$ of the bacterial community), but we found no evidence that they were grazed upon by Daphnia. Moreover, our results do not support the hypothesis that Daphnia harbored symbiotic MOB. Therefore, the isotopic composition of Daphnia could not be explained by direct trophic interactions with $\mathrm{MOB}$, suggesting the potential importance of indirect trophic interactions (e.g. consumption of MOB-feeding protists) or other processes that alter the isotopic composition of zooplankton resources (e.g. $\mathrm{CO}_{2}$ recycling).
\end{abstract}

KEY WORDS: Ecology · Symbiosis · Grazing · Methanotrophs · Methanogens · Dissolved organic carbon $\cdot \mathrm{DOC} \cdot \mathrm{Subsidy}$

\section{INTRODUCTION}

A fundamental goal of aquatic ecology is to understand how different sources of energy influence population, community, and ecosystem dynamics. While photosynthesis serves as the principal energy base in many systems, it is now recognized that aquatic food webs are fueled to varying degrees by other pathways involving the microbial loop (Azam 1998), terrestrial subsidies (Jansson et al. 2007), and benthic-pelagic coupling (Vander Zanden et al. 2005). An additional energy pathway that has attracted increasing interest is the potential for methane-derived carbon to be incorporated into aquatic food webs (Bastviken et al. 2003).

Significant quantities of methane $\left(\mathrm{CH}_{4}\right)$ are produced in anaerobic sediments of aquatic ecosystems. Owing to strong isotope fractionation during methano- genesis, $\mathrm{CH}_{4}$ has a ${ }^{13} \mathrm{C}$-depleted isotope signature $\left(\delta^{13} \mathrm{C}=-110\right.$ to $\left.-50 \%\right)$ that is distinct from other carbon sources in aquatic environments (Summons et al. 1994). Over the past few decades, many studies have attempted to reconstruct the flow of energy in aquatic food webs via inferences based on carbon stable isotope ratios (e.g. Peterson \& Fry 1987). Some of these studies have revealed that consumer populations (e.g. chironomids and crustacean zooplankton) in a variety of habitats have very low $\delta^{13} \mathrm{C}$ values (Bunn \& Boon 1993, Jones et al. 1999, 2008a, Grey et al. 2004, Kohzu et al. 2004). Such observations have led to the hypothesis that a significant fraction of aquatic consumer diets may be comprised of $\mathrm{CH}_{4}$-derived carbon. For example, results from a whole-lake isotope manipulation suggest that up to $50 \%$ of Daphnia biomass may come from $\mathrm{CH}_{4}$ (Taipale et al. 2008). Relatively few studies, however, have attempted to discern how $\mathrm{CH}_{4}$ - 
derived carbon is incorporated into aquatic food webs (but see Deines et al. 2007).

One way that $\mathrm{CH}_{4}$-derived carbon may enter aquatic food webs is through the consumption of $\mathrm{CH}_{4}$-oxidizing bacteria (methane-oxidizing bacteria [MOB] or methanotrophs). MOB, most of which belong to the alpha- and gamma-Proteobacteria, use $\mathrm{CH}_{4}$ as a carbon/energy source and oxygen $\left(\mathrm{O}_{2}\right)$ as a terminal electron acceptor. MOB are commonly found in aquatic sediments, where they co-occur with ${ }^{13} \mathrm{C}$-depleted invertebrates (Eller et al. 2005). Isotope labeling experiments have shown that ${ }^{13} \mathrm{C}$ depletion of chironomids is most likely due to the consumption of MOB (Deines et al. 2007). MOB also inhabit the water column of lakes and are abundant at transitions zones where there are high concentrations of $\mathrm{O}_{2}$ and $\mathrm{CH}_{4}$ (Carini et al. 2005). Zooplankton that encounter and feed on MOB in the lake water column should have a ${ }^{13} \mathrm{C}$-depleted isotopic signature. Support for this hypothesis comes from laboratory experiments that incubated Daphnia under elevated $\mathrm{CH}_{4}$ concentrations (Kankaala et al. 2006). Moreover, a recent study found that ${ }^{13} \mathrm{C}$-depleted Daphnia tend to have a high proportion of MOB phospholipid fatty acids (Taipale et al. 2009b). Together, these results suggest that the consumption of $\mathrm{MOB}$ may sometimes be an important trophic pathway for $\mathrm{CH}_{4}$-derived carbon in aquatic food webs.

A symbiotic association between aquatic invertebrate consumers and MOB is an alternative explanation for patterns of ${ }^{13} \mathrm{C}$-depletion in aquatic food webs. Marine invertebrates commonly form symbiotic relationships with MOB near hydrocarbon seep environments (Childress et al. 1986, Schmaljohann et al. 1990). Although MOB symbionts were not found in sediment-dwelling chironomids with ${ }^{13} \mathrm{C}$-depleted isotope signatures (Deines et al. 2007), growing evidence suggests that freshwater zooplankton often establish symbiotic relationships with a variety of microorganisms. For example, fluorescent in situ hybridization (FISH) and metagenomic screening has revealed that there are diverse assemblages of symbiotic bacteria associated with different Daphnia species (Peter \& Sommaruga 2008, Qi et al. 2009). Daphnia can form mutualistic associations with epibiotic algae (BareaArco et al. 2001) and endosymbiotic plastids (Chang \& Jenkins 2000), but also harbor bacterial parasites (Rodrigues et al. 2008). Many of these relationships between bacteria and Daphnia have demonstrable implications for symbiont and host population dynamics (Ebert et al. 2000), as well as for food web interactions (Hall et al. 2005).

Regardless of the mechanism of interaction, it appears that the importance of $\mathrm{CH}_{4}$-derived carbon in aquatic food webs is spatially and temporally variable (Jones et al. 2008a, Taipale et al. 2008). For example, it has been hypothesized that $\mathrm{CH}_{4}$ flow may be stronger in humic lakes because inputs of terrestrial-derived dissolved organic carbon (DOC) create conditions that promote methanogenesis (Jones et al. 1999, 2008, Houser et al. 2003, Lennon et al. 2006). In addition, the consumption and incorporation of $\mathrm{CH}_{4}$ into lake food webs appears to be highest in the fall, following summer stratification (Taipale et al. 2008). Based on these observations, we used a combination of stable isotope analysis, molecular biology, and bioassay experiments to assess the interactions between MOB and Daphnia in a humic lake prior to autumnal mixis. Our goal was to identify the mechanisms of interaction (consumptive or symbiotic) between MOB and Daphnia and, thus, clarify the microbial processes that influence the flow of $\mathrm{CH}_{4}$-derived carbon in planktonic food webs.

\section{MATERIALS AND METHODS}

Site description and sample collection. We collected water samples from Brandywine Lake located in southwestern Michigan (Van Buren County), USA, during mid-September 2008. Brandywine is a 29 ha, darkly stained, and productive waterbody $\left(\mathrm{DOC}=23.5 \mathrm{mg} \mathrm{l}^{-1}\right.$ chlorophyll $\mathrm{a}=15.6 \mu \mathrm{g} \mathrm{l^{-1 }}$, total phosphorus $=22.6 \mu \mathrm{g}$ $\mathrm{l}^{-1}$, total nitrogen $=0.93 \mathrm{mg} \mathrm{l}^{-1}$, Secchi depth $=0.75 \mathrm{~m}$ ). We measured temperature, $\mathrm{pH}$, and $\mathrm{O}_{2}$ at $0.5 \mathrm{~m}$ intervals with a Hydrolab Quanta probe (Hach Environmental). Using a horizontal Van Dorn sampler, we collected water at $0.5 \mathrm{~m}$ intervals from the surface to the maximum depth at $6 \mathrm{~m}$. These water samples were used for chemical, stable isotope, and molecular analyses. In addition, we used a $10 \mathrm{l}$ Schindler-Patalas trap with an $80 \mu \mathrm{m}$ mesh to capture zooplankton at $1 \mathrm{~m}$ intervals from 1 to $6 \mathrm{~m}$ depth. We identified crustacean zooplankton under a dissecting microscope according to Edmondson (1959). The zooplankton community in Brandywine Lake at the time of our sampling was dominated almost exclusively by Daphnia rosea, which is currently recognized as D. dentifera (Hebert 1995). The zooplankton samples were used for carbon stable isotope ratios, a bioassay experiment, and molecular analyses.

Stable isotope analyses. We measured the carbon stable isotope ratios of particulate organic matter (POM) and Daphnia for samples collected along a depth profile. For POM, we pre-filtered $150 \mathrm{ml}$ of water from each depth through a $35 \mu \mathrm{m}$ mesh and then collected this filtrate on pre-combusted GF/F filters $(0.7 \mu \mathrm{m})$. For Daphnia, we separated 75 to 100 ind. from large phytoplankton under a dissecting microscope and then filtered these animals onto precombusted GF/F filters. The filters were dried at $60^{\circ} \mathrm{C}$ prior to being analyzed at the Stable Isotope 
Facility of the University of California-Davis with a PDZ Europa trace gas analyzer and a continuousflow Europa 20/20 isotope ratio mass spectrometer (IRMS). Carbon stable isotope ratios were expressed using delta notation: $\delta^{13} \mathrm{C}=\left[\left(R_{\text {sample }} / R_{\text {reference }}\right)-1\right] \times$ 1000 , where $R$ is the ratio of ${ }^{13} \mathrm{C}$ to ${ }^{12} \mathrm{C}$ for samples and reference material (Vienna Peedee Belemnite).

Bioassay experiments. We conducted a bioassay experiment to test for a potential symbiotic relationship between Daphnia and MOB. We measured the rates of $\mathrm{CH}_{4}$ oxidation in incubations with and without Daphnia (+D and $-\mathrm{D}$, respectively). We predicted that $\mathrm{CH}_{4}$ oxidation would be higher in $+\mathrm{D}$ than in $-\mathrm{D}$ treatments if Daphnia harbored symbiotic MOB. Prior to initiating the experiment, we rinsed all of the field-collected Daphnia (pooled from the 4 to $6 \mathrm{~m}$ samples) to reduce the transfer of free-living MOB into the incubation vessels (160 ml serum bottles). Specifically, Daphnia were isolated from $10 \mathrm{ml}$ of field-collected zooplankton sample and concentrated to $3 \mathrm{ml}$ in a glass Petri dish using a Pasteur pipette. The Daphnia were then resuspended with $7 \mathrm{ml}$ of sterile COMBO medium (Kilham et al. 1998). This concentration-dilution procedure was repeated 4 times. For the $+\mathrm{D}$ treatment, we randomly assigned 50 Daphnia into replicate $(n=5)$ serum bottles containing $100 \mathrm{ml}$ of sterile COMBO medium. For the $-\mathrm{D}$ treatment, serum bottles with no animals ( $\mathrm{n}=5$ ) were filled with $100 \mathrm{ml}$ of sterile COMBO medium. Approximately $5 \mathrm{ml}$ of the zooplankton-rinsing medium was introduced to the serum bottles in the $+\mathrm{D}$ treatment. Therefore, as a control, we introduced $5 \mathrm{ml}$ of the same rinsing medium to the -D serum bottles. Each $160 \mathrm{ml}$ serum bottle was crimper-sealed with a $10 \mathrm{~mm}$ rubber septum and aluminum cap. We then added $10 \mathrm{ml}$ of a 10:90 $\mathrm{CH}_{4}$-He mix to the headspace of the $+\mathrm{D}$ and $-\mathrm{D}$ serum bottles while simultaneously removing $10 \mathrm{ml}$ of air to maintain ambient air pressure. This gas addition raised the concentration of dissolved $\mathrm{CH}_{4}$ to $14 \mathrm{\mu mol} \mathrm{l}^{-1}$. All serum bottles were incubated in the dark at room temperature for $90 \mathrm{~h}$ during which time there was negligible Daphnia mortality.

Gas analyses. We measured $\mathrm{CH}_{4}$ and carbon dioxide $\left(\mathrm{CO}_{2}\right)$ concentrations in Brandywine Lake by adding $50 \mathrm{ml}$ of a water sample to duplicate gas-evacuated serum bottles $(160 \mathrm{ml})$. Upon returning to the laboratory, we added $50 \mathrm{ml}$ of saturated $\mathrm{NaCl}$ solution and $60 \mathrm{ml}$ of He to each serum bottle (Lennon et al. 2006). The bottles were shaken vigorously prior to injecting 5 $\mathrm{ml}$ of headspace into a Shimadzu gas chromatograph (GC-14A) equipped with thermal conductivity (TCD) and flame ionization (FID) detectors. $\mathrm{CH}_{4}$ was separated with a Molecular Sieve 5A column and quantified by the FID. $\mathrm{CO}_{2}$ was separated from the same gas samples by a Porapak-Q packed column and quantified by the TCD. Absolute concentrations of $\mathrm{CH}_{4}$ and
$\mathrm{CO}_{2}$ were determined using single-point calibration with a mixed gas standard (Scotty Specialty Gases). Concentrations of $\mathrm{CH}_{4}$ and $\mathrm{CO}_{2}$ in the headspace of bioassay incubations were measured in a similar manner, but without saturated $\mathrm{NaCl}$ dissolution, and dissolved gas concentrations were estimated using Henry's Law.

Molecular analyses. We measured the abundance of MOB and total bacteria, both in the water column and in association with Daphnia, at various depths in Brandywine Lake. For quantification of MOB in the water column, $150 \mathrm{ml}$ of whole lake water from each Van Dorn sample was collected onto a $0.2 \mu \mathrm{m}$ filter and stored at $-20^{\circ} \mathrm{C}$ until further processing. For Daphnia, we processed live animals to gain insight into the potential physical association between MOB and zooplankton. Specifically, we isolated a total of 30 Daphnia from each of 3 depths $(4,5$, and $6 \mathrm{~m})$ in the lake. All of these animals were rinsed multiple times with sterile COMBO to minimize the inclusion of free-living MOB in DNA extractions (see subsection 'Bioassay experiments'). Half of the animals from each depth were transferred to tissue culture flasks $(70 \mathrm{ml})$ containing sterile COMBO media. These animals were held at room temperature in the dark for $48 \mathrm{~h}$ to allow for gut evacuation $(-\mathrm{G})$. The remaining animals with intact guts $(+\mathrm{G})$ were placed directly into $2 \mathrm{ml}$ centrifuge tubes. Both sets of animals $(+\mathrm{G}$ and $-\mathrm{G})$ were stored at $-20^{\circ} \mathrm{C}$ until DNA extraction.

We extracted DNA from $0.2 \mu \mathrm{m}$ filters (water samples) and Daphnia (+G and -G) using a FastPrep DNA purification kit (MP Biomedical). Then, 5 to $10 \mathrm{ng}$ of extracted DNA was used in all PCR and qPCR (quantitative polymerase chain reaction) runs. We generated qPCR standards by amplifying and cloning targets for each qPCR primer set from our Brandywine Lake water samples. Following PCR with qPCR primer sets and published conditions (Table 1; Kolb et al. 2003), we gel purified and cloned the products using a SpinPrep gel DNA kit (Novagen) and a TOPO TA cloning kit (Invitrogen). PCR with M13 primers was conducted on clones containing the qPCR amplicons, and we again gel purified the product using a SpinPrep gel DNA kit. We quantified the gel-purified M13 products using a Quant-iT PicoGreen dsDNA assay kit (Invitrogen) and used the purified products as standards for the corresponding qPCR assay. In addition, we used general pmoA and 16S rDNA PCR to determine if bacteria and MOB were associated with Daphnia (+G and -G). PCR primers (pmoA: A189F, 5'-GGN GAC TGG GAC TTC TGG-3'; A682r, 5'-CGS AAG AAG AGN CGS AAG-3'; 16S rDNA: 8f, 5'-AGA GTT TGA TCM TGG CTC AG3'; 1492r, 5'-GGT TAC CTT GTT ACG ACT T-3') and conditions have been published elsewhere (McDonald et al. 1999, Jones et al. 2008b). We assessed the pres- 
Table 1. Description of the primer sets used in the present study for quantitative PCR assays. Primer sequences are as follows: 189f, 5'-GGN GAC TGG GAC TTC TGG-3'; Mb601r, 5'-ACR TAG TGG TAA CCT TGY AA-3'; Mc468r, 5'-GCS GTG AAC AGG TAG CTG CC-3'; II223f, 5'-CGT CGT ATG TGG CCG AC-3'; II646r, 5'-CGT GCC GCG CTC GAC CAT GYG-3' (Kolb et al. 2003); 340f, 5'-TCC TAC GGG AGG CAG CAG-3'; 533r, 5'-TTA CCG CGG CTG CTG GCA C-3' (Newton et al. unpubl. data)

\begin{tabular}{|c|c|c|c|c|c|c|}
\hline Assay & $\begin{array}{l}\text { Forward } \\
\text { primer (F) }\end{array}$ & $\begin{array}{l}\text { Reverse } \\
\text { primer (R) }\end{array}$ & Target group & $\begin{array}{c}\text { F/R primer } \\
\text { concentration }(\mathrm{nM})\end{array}$ & $\begin{array}{c}\text { Annealing } \\
\text { temperature }\left({ }^{\circ} \mathrm{C}\right)\end{array}$ & $\begin{array}{l}\text { Data collection } \\
\text { temperature }\left({ }^{\circ} \mathrm{C}\right)\end{array}$ \\
\hline MBAC & $189 \mathrm{f}$ & Mb601r & Methylobacter/sarcina & $667 / 667$ & 54.0 & 82.0 \\
\hline MCOC & $189 \mathrm{f}$ & Mc468r & Methylococcus & $1000 / 333$ & 64.0 & 82.0 \\
\hline TypeII & II223f & II646r & Methylosinus/cystis & $667 / 667$ & 69.5 & 83.0 \\
\hline EUB & $340 \mathrm{f}$ & $533 r$ & Bacteria & $667 / 667$ & 68.0 & 83.5 \\
\hline
\end{tabular}

ence or absence of PCR products by visualizing gels $(1.5 \%$ agarose gels run at $50 \mathrm{~V})$ with a Gel Logic 200 gel imaging station and Kodak Molecular Imaging Software V 4.5.0

We used previously published qPCR assays for pmoA genes (Kolb et al. 2003). Primer sequences and qPCR conditions are listed in Table 1. The qPCR was conducted using BioRad iQ SYBR Green Mastermix and an Eppendorf Mastercycler ep realplex ${ }^{2}$ qPCR thermocycler. Standard curves and samples were run in duplicate for all assays. Standard curves always had efficiencies of between 0.9 and 1.1. Based upon negative control reactions and standard curves, our detection limit for all pmoA qPCR assays was $~ 10$ copies.

\section{RESULTS}

\section{Stable isotope profiles}

The carbon stable isotope ratios of particulate organic matter $\left(\delta^{13} \mathrm{C}_{\mathrm{POM}}\right)$ varied along the depth profile, with the most depleted value $(-33 \%)$ observed at $5 \mathrm{~m}$ and the most enriched value $(-27 \%)$ observed at $3 \mathrm{~m}$ near the oxycline (Fig. 1). The carbon stable isotope ratios of Daphnia $\left(\delta^{13} \mathrm{C}_{\mathrm{DAPH}}\right)$ were much less variable (range $=-32$ to $-34 \%$; Fig. 1), but were consistently depleted relative to $\delta^{13} \mathrm{C}_{\mathrm{POM}}$ (paired $t$-test, $\mathrm{p}=$ 0.002 , mean difference $=-2.85 \%$ ). There was a negative linear relationship between $\delta^{13} \mathrm{C}_{\mathrm{POM}}$ and $p m o A$ gene abundance $(\mathrm{r}=-0.56, \mathrm{n}=13, \mathrm{p}=0.048)$, suggesting that the isotopic composition of the putative food source for zooplankton may have been influenced by MOB. However, there was no relationship between $\delta^{13} \mathrm{C}_{\mathrm{DAPH}}$ and $p m o A$ gene abundance $(\mathrm{r}=-0.36, \mathrm{n}=6$, $\mathrm{p}=0.49)$.

\section{Distribution and abundance of MOB}

The patterns of MOB abundance in the water column were correlated with concentrations of $\mathrm{O}_{2}$ and $\mathrm{CH}_{4}$ in Brandywine Lake (Fig. 2A). As expected for a

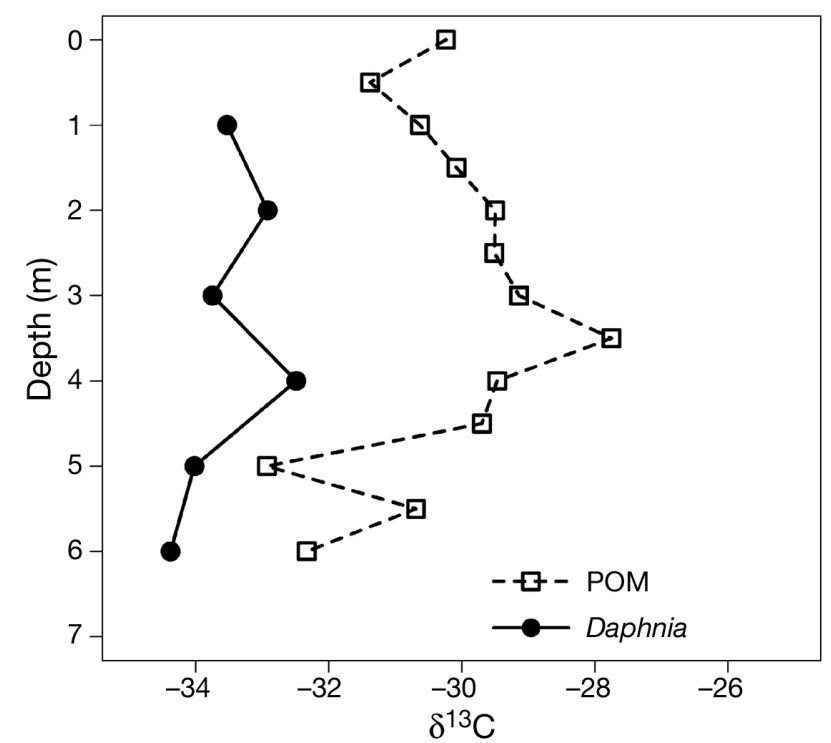

Fig. 1. Depth profile of carbon stable isotope ratios $\left(\delta^{13} \mathrm{C}\right)$ for particulate organic matter (POM) and Daphnia in Brandywine Lake, Michigan, USA, collected in mid-September 2008

humic lake, $\mathrm{O}_{2}$ concentrations declined rapidly with depth, reaching anoxic levels near the sediments (Fig. 2A). In contrast, $\mathrm{CH}_{4}$ concentrations were extremely low at shallow depths and highest near the sediments (Fig. 2A). Along this depth gradient, we observed major changes in the relative abundance of MOB. The maximum contribution of MOB to the total bacterial community $(\sim 3 \%)$ occurred at $5 \mathrm{~m}$. Even though pmoA genes were detected throughout the water column with $\mathrm{qPCR}$, the relative abundance of MOB steeply dropped off in samples above $\sim 4 \mathrm{~m}$ (Fig. 2A).

Our results indicate that Type I MOB were the primary $\mathrm{CH}_{4}$ oxidizers present in Brandywine Lake. Although we detected pmoA genes for Type II MOB, these taxa were $\geq 20$-fold less abundant (100 to 500 copies $\mathrm{ml}^{-1}$ ) than Type I MOB. Interestingly, our data provide evidence for potential vertical niche-partitioning between 2 of the predominant members of Type I MOB (Fig. 2B). Specifically, Methylobacter (MBAC) 


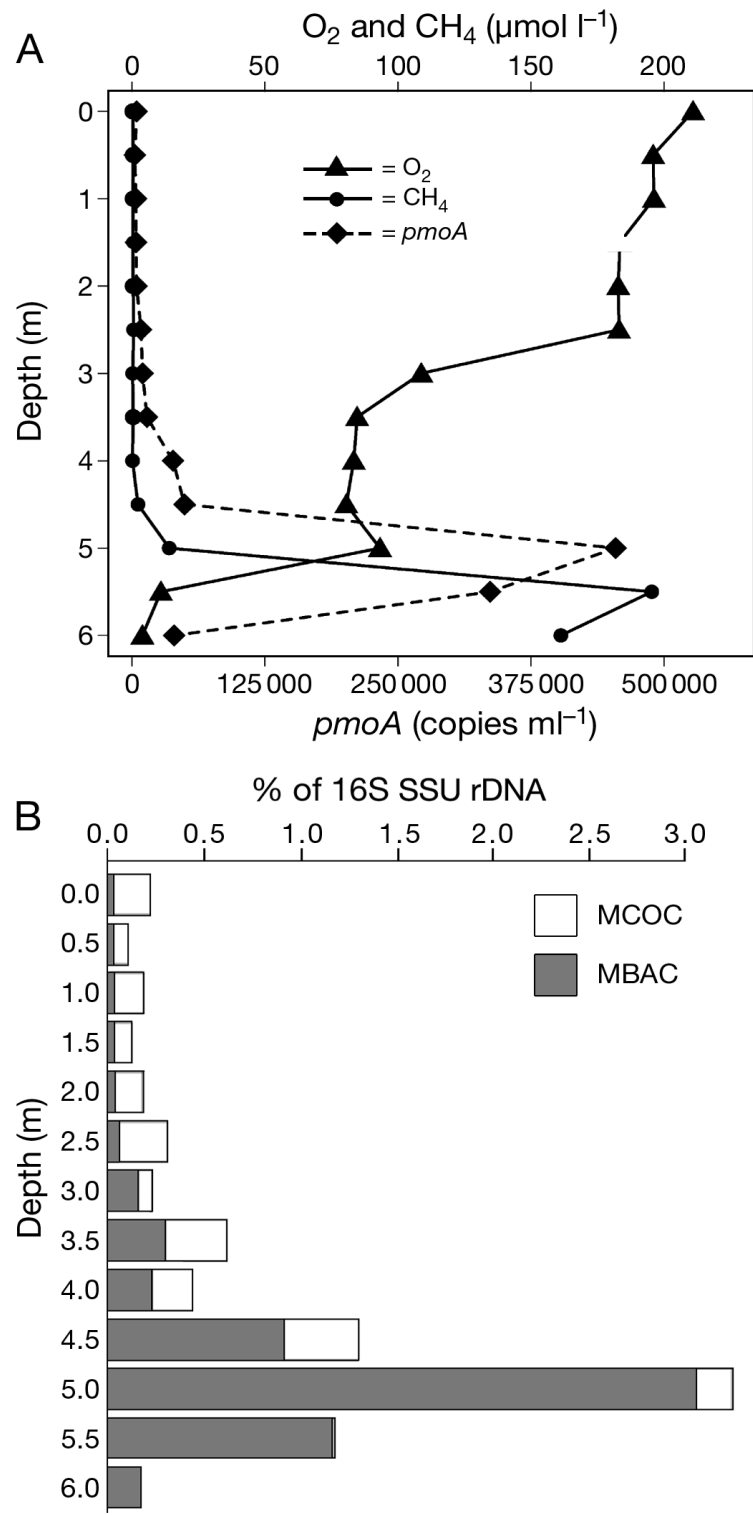

Fig. 2. (A) Profiles of $\mathrm{O}_{2}$ and $\mathrm{CH}_{4}$ concentrations in Brandywine Lake, Michigan, USA. The dashed line represents the number of particulate $\mathrm{CH}_{4}$ monooxygenase (pmoA) gene copies measured by quantitative PCR. (B) Proportion of Methylobacter-like (MBAC) and Methylococcus-like (MCOC) pmoA copies to 16S SSU rDNA copies in Brandywine Lake throughout the water column

was found in deeper water with higher $\mathrm{CH}_{4}$ and lower $\mathrm{O}_{2}$, while Methylococcus (MCOC) was found in shallower waters with lower $\mathrm{CH}_{4}$ and higher $\mathrm{O}_{2}$.

\section{MOB association with Daphnia}

Our molecular analysis of zooplankton-associated bacteria did not indicate that there was a strong consumptive or symbiotic relationship between Daphnia and $\mathrm{MOB}$ in Brandywine Lake. Had pmoA genes been recovered from animals with intact guts $(+\mathrm{G})$, then this would have suggested that MOB were a component of $D$. dentifera's diet. Alternatively, had $p m o A$ genes been recovered from gut-evacuated animals $(-G)$, then this would lend support to the hypothesis that MOB might have a symbiotic relationship with $D$. dentifera. Although we were able to detect bacteria associated with Daphnia, based on 16S ribosomal RNA genes, we were unable to detect pmoA genes associated with Daphnia, regardless of whether the animals had intact $(+G)$ or evacuated guts (-G) (Fig. 3).

\section{Bioassay experiments}

Rates of $\mathrm{CH}_{4}$ oxidation were $25 \%$ lower in the presence of Daphnia (+D) relative to the control (-D) treatment ( $t$-test, $\mathrm{p}<0.001$; Fig. 4). Although the $\mathrm{CH}_{4}$ oxidation rates were low, our results imply that the inoculum of COMBO medium that was used to rinse the zooplankton contained some MOB. More importantly, the results do not support the hypothesis that there is a symbiotic relationship between Daphnia and MOB. Rather, the results from our bioassay experiment suggest that Daphnia suppressed rates of $\mathrm{CH}_{4}$ oxidation by grazing upon MOB. In addition, rates of $\mathrm{CO}_{2}$ production were $550 \%$ higher in the $+\mathrm{D}$ treatment relative

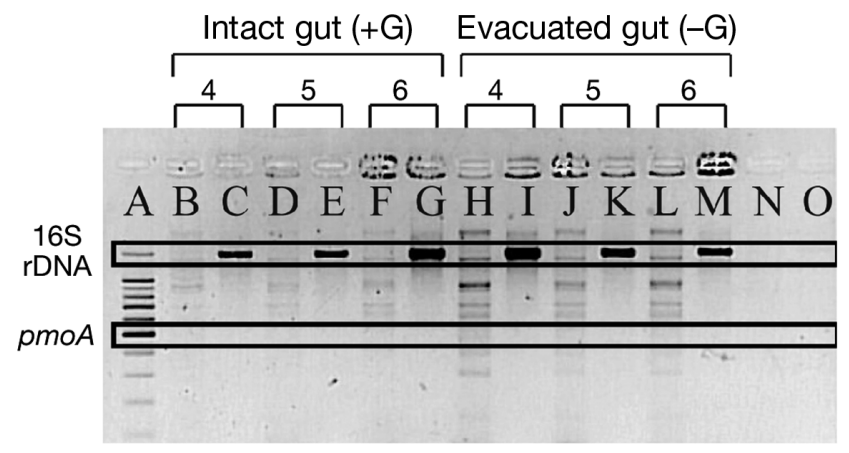

Fig. 3. To test whether $\mathrm{CH}_{4}$ oxidizing bacteria were present in Daphnia guts (ingested) or otherwise physically associated (potential symbiotic relationship), we attempted to amplify bacterial 16S rRNA and pmoA genes from Daphnia with intact (+G, Lanes B to $G$ ) and evacuated $(-G$, Lanes $H$ to $M)$ gut contents. We checked intact and evacuated Daphnia collected at 3 depths $(4,5$, and $6 \mathrm{~m})$, where we observed the highest concentrations of $\mathrm{CH}_{4}$. For each depth the left lane contained the $p m o A(189 \mathrm{~F}, 682 \mathrm{R}) \mathrm{PCR}$ product and the right lane contained the 16S rDNA (8F, 1492R) PCR product. Lane A contains a 100 base pair size standard, and Lanes $\mathrm{N}$ and $\mathrm{O}$ are negative control PCR reactions. Quantitative PCR likely provides a much lower level of detection and was used to confirm the gel-based inferences presented here. Water column samples were positive for both $16 \mathrm{~S}$ rRNA and pmoA genes (data not shown) 


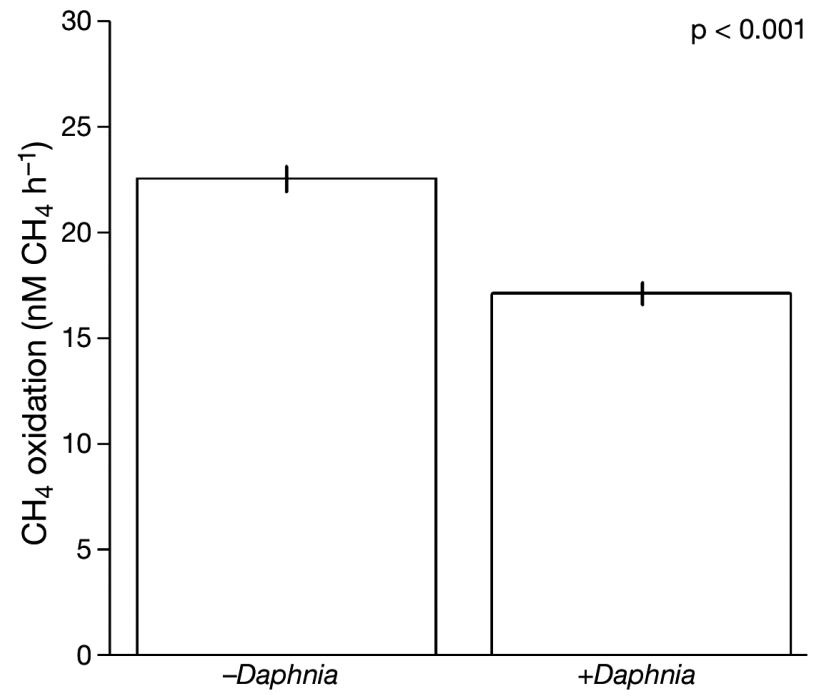

Fig. 4. Rates of $\mathrm{CH}_{4}$ oxidation in a laboratory bioassay experiment to test for the potential of a methanotroph symbiont associated with natural populations of Daphnia. Septum-sealed bioassay bottles contained COMBO medium with $14 \mu \mathrm{M} \mathrm{CH}_{4}$ and with (+D) or without (-D) Daphnia. Contrary to the symbiosis hypothesis, rates of $\mathrm{CH}_{4}$ oxidation were higher in the $-\mathrm{D}$ treatment than in the $+\mathrm{D}$ treatment, suggesting that methane-oxidizing bacteria activity was suppressed by topdown grazing. Bars represent means $( \pm$ standard error)

to the $-\mathrm{D}$ treatment $(t$-test, $\mathrm{p}<0.001)$, suggesting that Daphnia were metabolically active during the duration of the bioassay.

\section{DISCUSSION}

Recently, ecologists have become interested in $\mathrm{CH}_{4}$ as an alternative carbon and energy source in aquatic ecosystems. Observations that zooplankton biomass in many aquatic ecosystems is consistently depleted in ${ }^{13} \mathrm{C}$ relative to their putative food source (i.e. $\mathrm{POM}_{\text {; del }}$ Giorgio \& France 1996) suggest that $\mathrm{CH}_{4}$ may support secondary production in some aquatic food webs (Bunn \& Boon 1993, Jones et al. 1999). It has been hypothesized that the flow of $\mathrm{CH}_{4}$-derived carbon may be strongest in systems that have high concentrations of terrestrial-derived DOC because humic and fulvic acids create physical and chemical conditions that promote methanogenesis (Jones et al. 1999, Houser et al. 2003). In the present study, we observed that carbon pools in Brandywine Lake were moderately depleted in ${ }^{13} \mathrm{C}$ and that $\delta^{13} \mathrm{C}_{\mathrm{DAPH}}$ was significantly lower than $\delta^{13} \mathrm{C}_{\mathrm{POM}}$. Daphnia with comparable carbon isotope signatures have been shown to derive from 1 to $3 \%$ of their phospholipids from MOB (Taipale et al. 2009b). Such patterns have led to the hypothesis that there may be an important trophic link between $\mathrm{CH}_{4}$-oxidizing bacteria (MOB) and crustacean zooplankton, at least in some lakes at certain times of the year (e.g. Bastviken et al. 2003, Taipale et al. 2007). Therefore, Brandywine Lake provided us with an opportunity to mechanistically explore interactions between MOB and Daphnia using molecular analyses and bioassay experiments. Although MOB were present in the water column, we were unable to detect a physical association between MOB and Daphnia. These results indicate that MOB were probably a minor component of Daphnia diets and that a MOB-daphnid symbiosis was most likely absent. Even though our study found evidence for limited flow of $\mathrm{CH}_{4}$-derived carbon to Daphnia, results of our bioassay experiments support some studies that suggest crustacean zooplankton have the potential to impose strong top-down control on $\mathrm{MOB}$ activity (Kankaala et al. 2007).

\section{Water-column distribution and abundance of MOB}

Because aerobic methanotrophy typically requires $\mathrm{O}_{2}$ as an electron acceptor and $\mathrm{CH}_{4}$ as a carbon/energy source, we predicted that the maximum MOB densities would be found at the depth with the highest $\mathrm{O}_{2}$ and $\mathrm{CH}_{4}$ concentrations. Dissolved oxygen in Brandywine Lake had an initial drop-off at $2.5 \mathrm{~m}$, but remained at intermediate levels ( 75 to $100 \mu \mathrm{mol} \mathrm{l}^{-1}$ ) until $5.5 \mathrm{~m}$ where conditions became anoxic (Fig. 2A). In contrast, $\mathrm{CH}_{4}$ concentration peaked at $5.5 \mathrm{~m}$. The water-column MOB seemed to track the $\mathrm{CH}_{4}$ profile, but with a slight spatial lag, such that they reached their maximum abundance $(3 \%$ of the bacterial community) at a slightly shallower depth $(5 \mathrm{~m})$. This distributional pattern could either reflect the $\mathrm{O}_{2}$ requirements of $\mathrm{MOB}$ or the potential depletion of $\mathrm{CH}_{4}$ by MOB at their optimal depth.

Previous molecular studies in pelagic systems have documented the dominance of Type I MOB over Type II MOB (e.g. Eller et al. 2005, Lin et al. 2005). Consistent with this pattern, we found that Type I MOB were $\geq 20$-fold more abundant than Type II MOB in Brandywine Lake. Within the Type I MOB, growing evidence suggests that Methylobacter-related taxa are common in stratified lakes (Kojima et al. 2009, Taipale et al. 2009a). Our qPCR results generally support these observations, but indicate that Methylococcus-related taxa can also be an important component of the Type I MOB community. Specifically, Methylobacter-related taxa dominated at greater depths, whereas Methylococcus-related taxa were more abundant at shallower depths (Fig. 2B). This distributional pattern is suggestive of niche partitioning, which may reflect ecophysiological specialization. For example, variability in $\mathrm{O}_{2}$ and $\mathrm{CH}_{4}$ concentrations within the water column (Fig. 2A) might explain the 
vertical distribution of Type I MOB if there are consistent differences in the forms (i.e. soluble vs. particulate) or affinities of the methane monooxygenase used by Methylobacter and Methylococcus. Such mechanisms have been used to help explain the composition of terrestrial MOB and their associated enzyme kinetics in upland and lowland soils (Bender \& Conrad 1992, Baani \& Liesack 2008). Lastly, it is worth noting that there are distinct differences in the profiles of functional genes (i.e. soluble methane monooxygenase, ribulose-1,5-diphosophate carboxylase, and nitrogenase) for the Methylobacter- and Methylococcus-type strains (Hanson \& Hanson 1996). If conserved for all Methylobacter and Methylococcus, these genomic differences could have implications for the depth-specific fitness of $\mathrm{MOB}$ in the water column.

We detected a significant, but relatively weak, inverse correlation between $\mathrm{MOB}$ abundance and $\delta^{13} \mathrm{C}_{\mathrm{POM}}$. This result provides some of the first evidence that MOB may influence the isotopic composition of the putative food source (i.e. POM) of pelagic zooplankton. In contrast, MOB abundance was not correlated with $\delta^{13} \mathrm{C}_{\mathrm{DAPH}}$. There are multiple potential explanations for this lack of pattern. (1) Although Daphnia are often considered generalist grazers, they can exhibit 'non-random' feeding behaviors, either through selection of food particles or through patterns of vertical migration (Kerfoot \& Kirk 1991, Lampert \& Sommer 1997). (2) Owing to differences in the dimensions of our sampling devices, we were only able to sample Daphnia at 6 depths, whereas POM was sampled at 13 depths. Thus, we had reduced statistical power to detect a correlation between MOB abundance and $\delta^{13} \mathrm{C}_{\mathrm{DAPH}}$ along the depth profile. (3) Although our molecular analyses are extremely sensitive for detecting the presence of $\mathrm{MOB}$, these methods would not be able to track the flow of $\mathrm{CH}_{4}$-derived carbon if intermediate consumers (i.e. heterotrophic flagellates and ciliates) are an important trophic link between MOB and Daphnia. Phospholipid fatty acids (PLFA) would serve as a conservative microbial tracer if Daphnia consumed protists that grazed on MOB. An inverse relationship between $\delta^{13} \mathrm{C}_{\mathrm{DAPH}}$ and the percent of PLFA from MOB in a Finnish lake suggests that intermediate consumer links may be important for the flow of $\mathrm{CH}_{4}$-derived carbon in planktonic food webs (Taipale et al. 2009b).

\section{Daphnia - bacterial associations}

Numerous studies have demonstrated that bacteria can have strong physical associations with crustacean zooplankton (e.g. Grossart et al. 2009), including
Daphnia (Rodrigues et al. 2008). Similarly, our results indicate that bacteria (based upon 16S rDNA PCR product) were present in both gut-evacuated $(-\mathrm{G})$ and non-evacuated (+G) Daphnia. These data confirm that bacteria are both physically attached to and present in the guts of Daphnia. In contrast, PCR-based and qPCRbased sampling of $D$. dentifera for $p m o A$ genes indicated that daphnid-associated MOB were either absent or below our detection limit (10 gene copies) during late summer in Brandywine Lake. Thus, we have no evidence that MOB are either in the guts of Daphnia (+G) or physically attached to Daphnia (-G) in any other way. Although caveats exist when considering PCR-based techniques, these approaches have been successfully used to characterize parasites of Daphnia (e.g. Johnson et al. 2006) and potential MOB symbionts of Chironomus plumosus (Eller et al. 2007).

$\mathrm{A} \mathrm{CH}_{4}$-oxidizing symbiont is an alternative explanation for the observed depletion of zooplankton $\delta^{13} \mathrm{C}$ relative to their prey (Lennon et al. 2006). Strong symbiotic relationships between $\mathrm{MOB}$ and invertebrates have been documented at marine hydrocarbon seeps (Childress et al. 1986, Schmaljohann et al. 1990). It seems that anoxic aquatic sediments may serve as an analogous habitat that could select for a symbiotic association between $\mathrm{MOB}$ and freshwater invertebrates. However, our bioassay results corroborate our molecular surveys and suggest that Daphnia dentifera in Brandywine Lake lacked a symbiotic association with MOB. Metabolically active Daphnia were incubated in a $\mathrm{CH}_{4}$-rich environment with no other food source besides a residual amount of lake water that accompanied the transfer of animals into experimental incubation vessels. We predicted that the $+\mathrm{D}$ treatment would have higher rates of $\mathrm{CH}_{4}$ oxidation, when compared to controls without Daphnia (-D), owing to activity associated with hypothesized MOB symbionts. In contrast, we observed lower rates of $\mathrm{CH}_{4}$ oxidation in the $+\mathrm{D}$ versus $-\mathrm{D}$ treatments, suggesting that Daphnia actually had a 'top-down' effect on MOB activity. These results are consistent with a laboratory study that documented grazer control on rates of $\mathrm{CH}_{4}$ oxidation (Kankaala et al. 2007).

\section{Synthesis}

Together, the results from our stable isotope analyses, molecular approaches, and bioassay experiment suggest that MOB were unlikely to support Daphnia biomass production in Brandywine Lake during the time of our sampling. Some studies have suggested that the contribution of MOB to zooplankton production is temporally variable (Jones et al. 1999, Grey et al. 2001, Taipale et al. 2008). For example, based on stable 
isotope mixing models, it has been inferred that the maximum consumption of MOB by zooplankton occurs in humic lakes prior to autumnal mixis (Grey et al. 2001, Taipale et al. 2008). Despite our sampling of a very humic lake late in the fall season, we found no evidence that MOB were either consumed by or physically associated with $D$. dentifera in Brandywine Lake.

Other potential explanations for the observed $\delta^{13} \mathrm{C}_{\mathrm{DAPH}}$ patterns include the consumption of greensulfur bacteria (Taipale et al. 2008) or phytoplankton that have fixed ${ }^{13} \mathrm{C}$-depleted $\mathrm{CO}_{2}$, resulting from heterotrophic respiration (France et al. 1997). For example, the $\delta^{13} \mathrm{C}$ of dissolved inorganic carbon (DIC) can be as low as $-30 \%$ in some lakes (Bade et al. 2004). Phototrophs that use this DIC should become even more depleted owing to the isotopic fractionation associated with photosynthesis (Hayes 1993). This ' $\mathrm{CO}_{2}$ recycling' may be particularly important in humic systems like Brandywine Lake (Lennon et al. 2006). Therefore, it is not always necessary to evoke the incorporation of $\mathrm{CH}_{4}$-derived carbon to explain the isotopic composition of zooplankton in some lakes (Lennon et al. 2006).

Although our molecular data suggest $\mathrm{MOB}$ are a minor component of daphnid diets, results from our bioassay experiment indicated that Daphnia may have a strong 'top-down' influence on $\mathrm{MOB}$, reducing rates of $\mathrm{CH}_{4}$ oxidation by up to $25 \%$. Spatially subsidized consumers can derive much of their energy from one prey population and have strong top-down influences on another prey population, a process termed 'apparent competition' (Holt 1977). Based on the results of our bioassay, it seems apparent competition could occur between epilimnetic phytoplankton and $\mathrm{MOB}$ as a result of predation by Daphnia. In this scheme, Daphnia would derive the majority of their energy from the consumption of phytoplankton, but reduce $\mathrm{MOB}$ or $\mathrm{MOB}$-grazer population size via grazing pressure. This could occur without Daphnia deriving significant energetic gains from the interaction with MOB or MOB grazers (see Power 1990). Thus, it is possible that in addition to having strong top-down control on primary production in aquatic systems (Carpenter \& Kitchell 1993), Daphnia may also influence $\mathrm{CH}_{4}$ oxidation rates, but further research is necessary to determine whether this is a widespread phenomenon.

Acknowledgements. We acknowledge B. Lehmkuhl for assistance in the laboratory; K. Bird, E. Kane, T. Miller, A. Shade, J. Palange, R.I. Jones, and an anonymous reviewer for critical comments on an earlier version of the manuscript. Funding was provided by the National Science Foundation (DEB0842441) and the Center for Water Sciences (CWS) at Michigan State University. This is Contribution Number 1497 of the Kellogg Biological Station.

\section{LITERATURE CITED}

Azam F (1998) Microbial control of oceanic carbon flux: the plot thickens. Science 280:694-696

Baani M, Liesack W (2008) Two isozymes of particulate methane monooxygenase with different methane oxidation kinetics are found in Methylocystis sp. strain SC2. Proc Natl Acad Sci USA 105:10203-10208

Bade DL, Carpenter SR, Cole JJ, Hanson PC, Hesslein RH (2004) Controls of $\delta^{13} \mathrm{C}$-DIC in lakes: geochemistry, lake metabolism, and morphometry. Limnol Oceanogr 49: $1160-1172$

Barea-Arco J, Perez-Martinez C, Morales-Baquero R (2001) Evidence of a mutualistic relationship between an algal epibiont and its host, Daphnia pulicaria. Limnol Oceanogr 46:871-881

Bastviken D, Ejlertsson J, Sundh I, Tranvik L (2003) Methane as a source of carbon and energy for lake pelagic food webs. Ecology 84:969-981

> Bender M, Conrad R (1992) Kinetics of methane oxidation in oxic soils exposed to ambient air or high methane mixing ratios. FEMS Microbiol Ecol 101:261-270

> Bunn SE, Boon PI (1993) What sources of organic carbon drive food webs in billabongs? A study based on stable isotope analysis. Oecologia 96:85-94

Carini S, Bano N, LeCleir G, Joye SB (2005) Aerobic methane oxidation and methanotroph community composition during seasonal stratification in Mono Lake, California (USA). Environ Microbiol 7:1127-1138

Carpenter SR, Kitchell JF (1993) The trophic cascade in lakes. Cambridge University Press, Cambridge

Chang N, Jenkins DG (2000) Plastid endosymbionts in the freshwater crustacean Daphnia obtusa. J Crustac Biol 20: 231-238

Childress JJ, Fischer CR, Brooks JM, Kennicutt MCI, Bidigare R, Anderson AE (1986) A methanotrophic marine molluscan (Bivalvia: Mytilidae) symbiosis: mussels fueled by gas. Science 233:1306-1308

> Deines P, Bodelier PLE, Eller G (2007) Methane-derived carbon flows through methane-oxidizing bacteria to higher trophic levels in aquatic systems. Environ Microbiol 9: 1126-1134

del Giorgio PA, France RL (1996) Ecosystem-specific patterns in the relationship between zooplankton and POM or microplankton $\delta^{13} \mathrm{C}$. Limnol Oceanogr 41:359-365

- Ebert D, Lipsitch M, Mangin KL (2000) The effect of parasites on host population density and extinction: experimental epidemiology with Daphnia and six microparasites. Am Nat 156:459-477

Edmondson WT (1959) Fresh-water biology. John Wiley and Sons, New York

Eller G, Deines P, Grey J, Richnow HH, Kruger M (2005) Methane cycling in lake sediments and its influence on chironomid larval partial derivative ${ }^{13} \mathrm{C}$. FEMS Microbiol Ecol 54:339-350

Eller G, Deines P, Kruger M (2007) Possible sources of methane-derived carbon for chironomid larvae. Aquat Microb Ecol 46:283-293

> France RL, del Giorgio PA, Westcott KA (1997) Productivity and heterotrophy influences on zooplankton delta ${ }^{13} \mathrm{C}$ in northern temperate lakes. Aquat Microb Ecol 12:85-93

Grey J, Jones RI, Sleep D (2001) Seasonal changes in the importance of the source of organic matter to the diet of zooplankton in Loch Ness, as indicated by stable isotope analysis. Limnol Oceanogr 46:505-513

> Grey J, Kelly A, Ward S, Sommerwerk N, Jones RI (2004) Seasonal changes in the stable isotope values of lake- 
dwelling chironomid larvae in relation to feeding and life cycle variability. Freshw Biol 49:681-689

Grossart HP, Dziallas C, Tang KW (2009) Bacterial diversity associated with freshwater zooplankton. Environ Microbiol Rep 1:50-55

Hall SR, Duffy MA, Caceres CE (2005) Selective predation and productivity jointly drive complex behavior in host-parasite systems. Am Nat 165:70-81

- Hanson RS, Hanson TE (1996) Methanotrophic bacteria. Microbiol Rev 60:439-471

- Hayes JM (1993) Factors controlling ${ }^{13} \mathrm{C}$ contents of sedimentary organic compounds - principles and evidence. Mar Geol 113:111-125

Hebert PDN (1995) The Daphnia of North America: an illustrated fauna. CyberNatural Software, University of Guelph, Guelph, ON

Holt RD (1977) Predation, apparent competition, and structure of prey communities. Theor Popul Biol 12:197-229

Houser JN, Bade DL, Cole JJ, Pace ML (2003) The dual influences of dissolved organic carbon on hypolimnetic metabolism: organic substrate and photosynthetic reduction. Biogeochemistry 64:247-269

> Jansson M, Persson L, De Roos AM, Jones RI, Tranvik L (2007) Terrestrial carbon and intraspecific size-variation shape lake ecosystems. Trends Ecol Evol 22:316-322

Johnson PTJ, Longcore JE, Stanton DE, Carnegie RB, Shields JD, Preu ER (2006) Chytrid infections of Daphnia pulicaria: development, ecology, pathology and phylogeny of Polycaryum laeve. Freshw Biol 51:634-648

> Jones RI, Grey J, Sleep D, Arvola L (1999) Stable isotope analysis of zooplankton carbon nutrition in humic lakes. Oikos 86:97-104

Jones RI, Carter CE, Kelly A, Ward S, Kelly DJ, Grey J (2008a) Widespread contribution of methane-cycle bacteria to the diets of lake profundal chironomid larvae. Ecology 89: $857-864$

> Jones SE, Newton RJ, McMahon KD (2008b) Potential for atmospheric deposition of bacteria to influence bacterioplankton communities. FEMS Microbiol Ecol 64:388-394

Kankaala P, Taipale S, Grey J, Sonninen E, Arvola L, Jones RI (2006) Experimental delta ${ }^{13} \mathrm{C}$ evidence for a contribution of methane to pelagic food webs in lakes. Limnol Oceanogr 51:2821-2827

Kankaala P, Eller G, Jones RI (2007) Could bacterivorous zooplankton affect lake pelagic methanotrophic activity? Fundam Appl Limnol/Arch Hydrobiol 169:203-209

Kerfoot WC, Kirk KL (1991) Degree of taste discrimination among suspension feeding cladocerans and copepodsimplications for detritivory and herbivory. Limnol Oceanogr 36:1107-1123

Kilham SS, Kreeger DA, Lynn SG, Goulden CE, Herrera L (1998) COMBO: a defined freshwater culture medium for algae and zooplankton. Hydrobiologia 377:147-159

Kohzu A, Kato C, Iwata T, Kishi D, Murakami M, Nakano S, Wada E (2004) Stream food web fueled by methanederived carbon. Aquat Microb Ecol 36:189-194

Kojima H, Iwata T, Fukui M (2009) DNA-based analysis of planktonic methanotrophs in a stratified lake. Freshw Biol 54:1501-1509

Editorial responsibility: Paul del Giorgio, Montréal, Québec, Canada
Kolb S, Knief C, Stubner S, Conrad R (2003) Quantitative detection of methanotrophs in soil by novel pmoAtargeted real-time PCR assays. Appl Environ Microbiol 69:2423-2429

Lampert W, Sommer U (1997) Limnoecology. Oxford University Press, New York

Lennon JT, Faiia AM, Feng XH, Cottingham KL (2006) Relative importance of $\mathrm{CO}_{2}$ recycling and $\mathrm{CH}_{4}$ pathways in lake food webs along a dissolved organic carbon gradient. Limnol Oceanogr 51:1602-1613

> Lin JL, Joye SB, Scholten JCM, Schafer H, McDonald IR, Murrell JC (2005) Analysis of methane monooxygenase genes in Mono Lake suggests that increased methane oxidation activity may correlate with a change in methanotroph community structure. Appl Environ Microbiol 71: 6458-6462

McDonald IR, Upton M, Hall G, Pickup RW and others (1999) Molecular ecological analysis of methanogens and methanotrophs in blanket bog peat. Microb Ecol 38:225-233

> Peter H, Sommaruga R (2008) An evaluation of methods to study the gut bacterial community composition of freshwater zooplankton. J Plankton Res 30:997-1006

> Peterson BJ, Fry B (1987) Stable isotopes in ecosystem studies. Annu Rev Ecol Syst 18:293-320

> Power ME (1990) Effects of fish in river food webs. Science 250:811-814

> Qi W, Nong G, Preston JF, Ben-Ami F, Ebert D (2009) Comparative metagenomics of Daphnia symbionts. BMC Genomics 10:172

> Rodrigues JLM, Duffy MA, Tessier AJ, Ebert D, Mouton L, Schmidt TM (2008) Phylogenetic characterization and prevalence of 'Spirobacillus cienkowskii,' a red-pigmented, spiral-shaped bacterial pathogen of freshwater Daphnia species. Appl Environ Microbiol 74:1575-1582

Schmaljohann R, Faber E, Whiticar MJ, Dando PR (1990) Coexistence of methane-based and sulfur-based endosymbioses between bacteria and invertebrates at a site in the Skagerrak. Mar Ecol Prog Ser 61:119-124

Summons RE, Jahnke LL, Roksandic Z (1994) Carbon isotopic fractionation in lipids from methanotrophic bacteria-relevance for interpretation of the geochemical record of biomarkers. Geochim Cosmochim Acta 58: 2853-2863

Taipale S, Kankaala P, Jones RI (2007) Contributions of different organic carbon sources to Daphnia in the pelagic foodweb of a small polyhumic lake: results from mesocosm $\mathrm{DI}^{13} \mathrm{C}$-additions. Ecosystems 10:757-772

Taipale S, Kankaala P, Tiirola M, Jones RI (2008) Whole-lake dissolved inorganic ${ }^{13} \mathrm{C}$ additions reveal seasonal shifts in zooplankton diet. Ecology 89:463-474

Taipale S, Jones RI, Tiirola M (2009a) Vertical diversity of bacteria in an oxygen-stratified humic lake, evaluated using DNA and phospholipid analyses. Aquat Microb Ecol 55:1-16

Taipale S, Kankaala P, Hamalainen H, Jones RI (2009b) Seasonal shifts in the diet of lake zooplankton revealed by phospholipid fatty acid analysis. Freshw Biol 54:90-104

Vander Zanden MJ, Essington TE, Vadeboncoeur Y (2005) Is pelagic top-down control in lakes augmented by benthic energy pathways? Can J Fish Aquat Sci 62:1422-1431

Submitted: March 24, 2009; Accepted: July 03, 2009

Proofs received from author(s): September 30, 2009 